\title{
Effect of Electroacupuncture on Glucostasis in Diabetic Rats
}

\author{
HESHAM A.D. ABDEL-RAZEK, M.D.; GERGESS S. HANNA, M.D.; SUZAN M. HAZAA, M.D.; \\ GHADA S. AMER, M.D.; SHAIMAA M. ABDEL GHANY, M.D. and REDA A.A. ABOEL SOUD, M.Sc.
}

The Department of Medical Physiology, Faculty of Medicine, Menoufia University, Egypt

\begin{abstract}
Background: Diabetes mellitus (DM) is a major international health problem characterized by an absolute or relative deficiency in the production or action of insulin, which results in hyperglycemia. Acupuncture is a part of traditional Chinese medicine (TCM) and is most commonly used form of alternative medicine, its modulatory effects are mediated by regulation of physiological state of the human body.

Aim of Study: The present study was designed to evaluate the possible ameliorating role of Electroacupuncture (EA) on the changes of fasting glucose, insulin, glycosylated hemoglobin HbA1c, C peptide levels, liver glycogen and glucose produced by kidneys in diabetic rats.

Material and Methods: Sixty adult male albino rats were used in this investigation, divided into following groups: Nondiabetic (C), diabetic (D), diabetic insulin treated (D+I), diabetic (EA) treated $(\mathrm{D}+\mathrm{E})$ and diabetic insulin and EAtreated $(\mathrm{D}+\mathrm{I}+\mathrm{E})$. Blood samples were collected for estimation of fasting blood glucose (FBG), insulin, (HbAlc) and C peptide levels. Liver and kidneys are removed for estimation of liver glycogen and glucose produced by kidneys.

Results: Significant decrease in fasting blood glucose level, (HbAlc,) and glucose produced by kidneys with significant increase in serum insulin, $\mathrm{C}$ peptide and liver glycogen in both diabetic insulin treated and diabetic (EA) treated groups compared with the diabetic group, but with significant change between the two groups. There was insignificant change between diabetic insulin and EA-treated $(\mathrm{D}+\mathrm{I}+\mathrm{E})$ group and non-diabetic (C) group. Conclusion: EA can be used as an adjuvant therapy in diabetic rats.
\end{abstract}

Key Words: Electroacupuncture - Acupoints - C peptide Rats.

\section{Introduction}

DIABETES mellitus (DM) is a major international health problem characterized by an absolute or relative deficiency in the production or action of insulin, which results in hyperglycemia [1]. Unfortunately, long term insulin administration in patients

Correspondence to: Dr. Hesham A.D. Abdel-Razek, The Department of Medical Physiology, Faculty of Medicine, Menoufia University, Egypt with DM resulting in insulin resistance, therefore, researchers have searched for complementary treatment methods with no side effects to increase insulin sensitivity [2].

Physiologically, preproinsulin is converted to proinsulin in endoplasmic retinaculum of beta cells of pancreas by microsomal enzymes, the proinsulin is converted to insulin and C peptide in Golgi apparatus then secreted into the portal circulation in equimolar concentrations [3]. Additionally, liver clears a significant portion of insulin in a first pass, but C-peptide does not undergo hepatic extraction and its half-life is about 10 times longer than that of insulin. Thus, serum C peptide is used as a marker for monitoring endogenous insulin production rather than serum insulin level [4].

Acupuncture is a part of traditional Chinese medicine (TCM) and is most commonly used form of alternative medicine. It is a meridian-based therapy, through which needles are inserted into specific points on the body, each of which has distinct therapeutic actions. According to (TCM), when an acupuncture point is stimulated, treatment effects tend to occur on the corresponding parts of the body [5]. The aim of this work is to study the possible ameliorating role of EA on the changes of fasting glucose level, insulin level, HbA1c, C peptide, liver glycogen and glucose produced by kidneys in diabetic rats.

\section{Patients and Methods}

The present study was carried out at Physiology Department, Faculty of Medicine, Menoufia University, Egypt at July 2017.

Equipments: Electro-needle therapy device for electro acupuncture (KWD-808 II, Multi-purpose health device, China) and Stainless steel acupuncture needle. 
Chemicals: Streptozotocin, (STZ) (Sigma Chemical Company, USA), kits for estimation of serum glucose (Biodiagnostic Company, Egypt), kits for estimation of glycosylated hemoglobin (Riomidi, France), insulin ELISA kits (DRG Instruments GmbH, Germany), C-Peptide ELISA Assay Kit (Eagle Biosciences, USA), kits for estimation the rate of hepatic glycogenesis (glycogen powder, trichloroacetic acid and silver sulfate, Biodiagnostic Company, Egypt) and kits for estimation the rate of renal gluconeogenesis (X.ketoglutarate powder, Biodiagnostic Company, Egypt).

\section{Experimental animals:}

Sixty adult male albino rat of local strain, weighing (200-250) grams each were used in this work. Rats were got from a licensed trainer, kept on standard laboratory chow, water \& libitum, housed in the animal house in cages measured $70 \times 70 \times 60 \mathrm{~cm}, 5$ animals/cage under normal light/ dark cycle and room temperature $\left(24-30^{\circ} \mathrm{C}\right)$ throughout the study period. The animals were classified into the following groups.

Group I: Control non diabetic $(n=12)(C)$ group:

Rats were injected subcutaneously with saline in a dose of $0.2 \mathrm{ml} / 100 \mathrm{gm} \mathrm{B}$.W/day, 6 days per week for 8 weeks.

Group II: Diabetic non treated $(n=12)(D)$ group:

Diabetes mellitus was induced by a single intraperitoneal injection of STZ $(45 \mathrm{mg} / \mathrm{Kg})$ in 10 $\mathrm{mmol} / \mathrm{L}$ in citrate buffer $(\mathrm{pH} 4.5)$ [6].

\section{Group III: Diabetic insulin treated $(n=12)(D+I)$ group:}

Diabetic rats were treated with mixtard insulin subcutaneously in a dose of $0.75 \mathrm{IU} / 100 \mathrm{gm} \mathrm{B.W}$, once daily, 6 days per week for 8 weeks [7]

\section{Group IV: Diabetic (EA) treated $(n=12)(D+E)$ group:}

Diabetic rats were submitted to EA on bilateral Zusanli acupoints or (ST-36) for 15 minutes three times/week [8] for 8 weeks [9].

\section{Group V: Diabetic insulin and EA treated (12 rats) $(D+I+E)$ group:}

Diabetic rats were treated with mixtard insulin subcutaneously in a dose of $0.75 \mathrm{IU} / 100 \mathrm{gm} \mathrm{B}$.W once daily, 6 days per week for 8 weeks and EA on bilateral Zusanli acupoints or (ST-36) for 15 minutes three times/week for 8 weeks.

Electroacupuncture (EA) technique: EA needles were inserted to a depth of $5 \mathrm{~mm}$ into the skin and underlying muscles at Zusanli acupoints (ST-36) bilaterally [10]. ST-36 is located at $5 \mathrm{~mm}$ lateral and lower from the anterior tubercle of the tibia in rats [11]. EA apparatus was adjusted with electrical square pulse width $(0.1 \mathrm{~ms}, 1 \mathrm{~mA}$ and $2 \mathrm{~Hz})$ were made. The positive charge was connected to the acupoint on the right leg and the negative charge on the left leg.

\section{Blood samples and biochemical assay:}

At the end of the experimental period ( 8 weeks).

1- Rats were fasted for 12 hours, morning retroorbital venous blood samples were collected using fine heparinized capillary tubes for measuring $\mathrm{HbA} 1 \mathrm{c}$. Other blood samples were collected in a clean graduated centrifugal tube, were left for clotting for 30 minutes at room temperature and then centrifuged at $3000 \mathrm{rpm}$ for 15 minutes. Serum samples was collected for estimation of fasting blood glucose, insulin and $\mathrm{C}$ peptide levels.

2- Removal of the liver for estimation the rate of hepatic glycogenesis by spectrophotometer using calorimetric diagnostic kits purchased from Biodiagnostic Company (Cairo, Egypt), according to manufacturer's instructions.

3- Removal of the kidneys for estimation the rate of renal gluconeogenesis by spectrophotometer using calorimetric diagnostic kits purchased from Biodiagnostic Company (Cairo, Egypt), according to manufacturer's instructions.

\section{Statistical analysis:}

The IBM company-SPSS program (Chicago, USA, SPSS Inc.) version 16.0 was used for analysis of data. The results were expressed as mean $\pm \mathrm{SD}$. The significance of differences between groups was determined by one-way analysis of variance with the post hoc of Tukey's multiple comparison tests. $p$-values $<0.05$ were considered statistically significant.

\section{Results}

The presented Table (1) demonstrate the fasting blood glucose level, serum insulin, glycosylated hemoglobin and serum $C$ peptide levels of the different experimental groups. The fasting blood glucose in diabetic (D) group was significantly higher $(p<0.05)$ compared to control non diabetic (C) group. In diabetic insulin treated group (D+I) group, the fasting blood glucose was significantly higher $(p<0.05)$ compared to the control non diabetic $(\mathrm{C})$ and significantly lower $(p<0.05)$ compared to diabetic non treated (D) group. In diabetic EA treated group (D+E) group, the fasting blood glu- 
cose was significantly higher $(p<0.05)$ compared to $(C)$ and $(D+I)$ groups, significantly lower $(p<0.05)$ when compared to the corresponding values of (D) group. In diabetic insulin and EA treated (D+I+ E) group, fasting blood glucose was significantly lower $(p<0.05)$ compared to (D), $(\mathrm{D}+\mathrm{I})$ and $(\mathrm{D}+\mathrm{E})$ groups, insignificantly changed $(p>0.05)$, compared to (C) group.

Table (1): Fasting blood glucose, serum insulin, glycosylated hemoglobin and serum C peptide levels in
control non diabetic (C), diabetic (D), diabetic insulin treated (D+I) diabetic EA treated (D+E)
and diabetic insulin and EA treated (D+I+E) gruops.

Results ate expressed as mean \pm S.D $(n=12)$. Significance was considered when $p$-value $\leq 0.05$.

The marks *,\#, $\Omega$ and $\sum$ Indicate that values of $C, D, D+I$ and $D+E$ groups, respectively.

Regarding serum insulin level, diabetic (D) group showed significantly lower insulin level $(p<0.05)$ than control non diabetic group. In diabetic insulin treated (D+I) group, serum insulin was significantly less $(p<0.05)$ than that of $(C)$ group but significantly high $(p<0.05)$ than that of (D) group. In diabetic EA treated $(\mathrm{D}+\mathrm{E})$, the serum insulin was significantly lower $(p<0.05)$ compared to $(C)$ and $(\mathrm{D}+\mathrm{I})$ groups, significantly higher $(p<0.05)$ compared to (D) group. In diabetic insulin and EA treated $(\mathrm{D}+\mathrm{I}+\mathrm{E})$ group, the serum insulin was significantly higher $(p<0.05)$ when compared to the corresponding values of (D), (D+I) and $(\mathrm{D}+\mathrm{E})$ groups, insignificantly changed $(p>0.05)$ when compared to the corresponding values of $(\mathrm{C})$ group.

On measurement of $\left(\mathrm{HbA}_{1_{\mathrm{c}}}\right)$, in diabetic (D) group, $\left(\mathrm{HbA}_{1_{\mathrm{c}}}\right)$ as percentage of normal $\mathrm{Hb}$ was significantly higher $(p<0.05)$ when compared to control non diabetic $(C)$ group. In diabetic insulin treated $(\mathrm{D}+\mathrm{I})$ group, $\left(\mathrm{HbA}_{1_{\mathrm{c}}}\right)$ level \% was significantly higher $(p<0.05)$ when compared to $(\mathrm{C})$ group and significantly lower $(p<0.05)$ when compared to (D) group. In diabetic EA treated (D+E) group, $\left(\mathrm{HbA}_{1_{\mathrm{c}}}\right)$ level \% was significantly higher $(p<0.05)$ when compared to $(\mathrm{C})$ and $(\mathrm{D}+\mathrm{I})$ groups, significantly lower $(p<0.05)$ when compared to (D) group. In diabetic insulin and EA treated $(\mathrm{D}+\mathrm{I}+\mathrm{E})$ group, $\left(\mathrm{HbA}_{1_{c}}\right)$ level \% significantly lower $(p<0.05)$ when compared to (D), (D+I) and (D+E) groups, insignificantly changed $(p>0.05)$, when compared to (C) group.

Concerning serum $\mathrm{C}$ peptide level, in diabetic (D) group, it was significantly lower $(p<0.05)$ when compared to control non diabetic (C) group. In diabetic insulin treated $(\mathrm{D}+\mathrm{I})$, serum $\mathrm{C}$ peptide was significantly lower $(p<0.05)$ when compared to (C) group and significantly higher $(p<0.05)$ when compared to the (D) group. In diabetic EA treated (D+E) group, serum $C$ peptide was significantly lower $(p<0.05)$ when compared to the $(\mathrm{C})$ group and significantly higher $(p<0.05)$ when compared to (D) and (D+I) groups. In diabetic insulin and EA treated $(\mathrm{D}+\mathrm{I}+\mathrm{E})$ group, serum $\mathrm{C}$ peptide was significantly higher $(p<0.05)$ when compared to (D), (D+I) and (D+E) groups and insignificantly changed $(p>0.05)$ when compared to (C) group.

\section{Liver glycogen and renal glucose levels:}

Fig. (1): Illustrates the mean $\pm \mathrm{SD}$ of liver glycogen level in the different experimental groups.

Diabetic (D) group showed significantly lower liver glycogen level $(11.6 \pm 0.54 \mathrm{mg} / \mathrm{g}, p<0.05)$ than control non diabetic (C) group $(35.3 \pm 0.33 \mathrm{mg} / \mathrm{g})$. In diabetic insulin treated (D+I) group, liver glycogen, was significantly less $(26.3 \pm 0.47 \mathrm{mg} / \mathrm{g}$, $p<0.05)$ than that of $(C)$ group but significantly high $(p<0.05)$ than that of (D) group. In diabetic EA treated $(\mathrm{D}+\mathrm{E})$, the liver glycogen was significantly lower $(17.2 \pm 0.5 \mathrm{mg} / \mathrm{g}, p<0.05)$ compared to $(\mathrm{C})$ and $(\mathrm{D}+\mathrm{I})$ groups, significantly higher $(p<0.05)$ compared to (D) group. In diabetic insulin and EA treated $(\mathrm{D}+\mathrm{I}+\mathrm{E})$ group, the liver glycogen was significantly higher $(34.8 \pm 0.48 \mathrm{mg} / \mathrm{g}, p<0.05)$ when compared to the corresponding values of (D), (D+I) and $(\mathrm{D}+\mathrm{E})$ groups, insignificantly changed $(p>0.05)$ when compared to the corresponding values of $(C)$ group. 
Fig. (2): Illustrates the mean \pm SD of glucose produced by kidneys in the different experimental groups.

In diabetic (D) group, glucose produced was significantly higher $(2.62 \pm 0.1 \mathrm{mg} / \mathrm{g}, p<0.05)$ when compared to control non diabetic (C) group (1.34 \pm $0.05 \mathrm{mg} / \mathrm{g})$. In diabetic insulin treated $(\mathrm{D}+\mathrm{I})$ group, glucose produced was significantly higher $(1.74 \pm$ $0.07 \mathrm{mg} / \mathrm{g}, p<0.05)$ when compared to $(\mathrm{C})$ group and significantly lower $(p<0.05)$ when compared

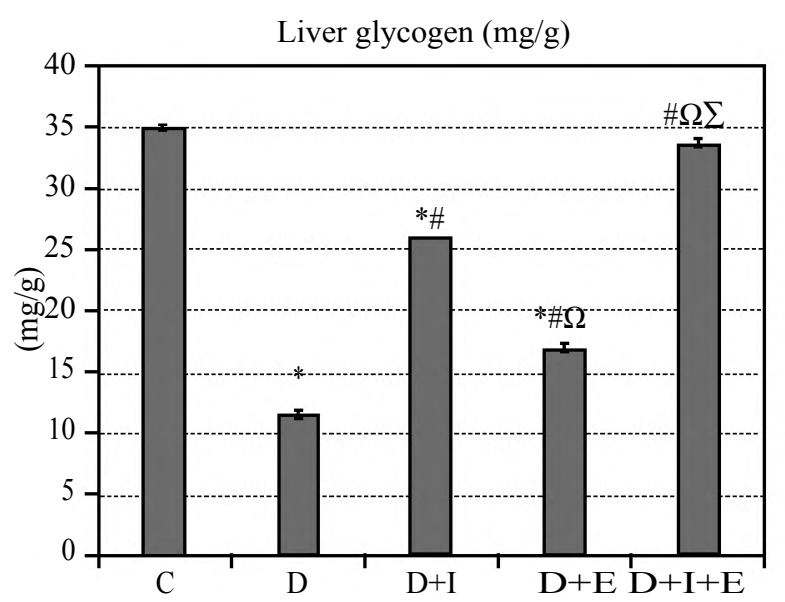

Fig. (1): Level of liver glycogen level (mg/g liver tissue) in control non diabetic (C), diabetic (D), diabetic insulin treated $(\mathrm{D}+\mathrm{I})$ diabetic EA treated $(\mathrm{D}+\mathrm{E})$ and diabetic insulin and EA treated $(\mathrm{D}+\mathrm{I}+\mathrm{E})$ gruops. Results are expressed as mean \pm S.D $(\mathrm{n}=12)$. Significance was considered when $p$-value $\leq 0.05$. The marks $*, \#, \Omega$ and $\sum$ indicate that values are significantly different when compared with the corresponding values of C,D,D+I and $\mathrm{D}+\mathrm{E}$ groups, respectively.

\section{Discussion}

In the present study, following STZ injection there was a significant decrease in the serum insulin together with a significant increase in the serum glucose concentrations compared to the corresponding values in the non-diabetic group. These results were in line with the reports of many researchers that stated that, following STZ injection in animals, almost $\beta$-cells undergo necrosis with consequent insulin deficiency and an overwhelming hyperglycemia [12] . In this work, insulin administration for 8 weeks to the diabetic rats (in insulin treated group) could significantly change the serum insulin and the glucose levels compared to those obtained results of the diabetic group. In support with these findings, Stang \& Story [13], had found that insulin is the most effective medication that lowers blood glucose levels in diabetes. Insulin serves as the primary regulator of blood glucose by increasing glucose uptake in muscle and fat tissues. It stimulates the translocation of the glucose transporter to (D) group. In diabetic EA treated (D+E) group, glucose produced was significantly higher $(2.13 \pm$ $0.08 \mathrm{mg} / \mathrm{g}, p<0.05$ ) when compared to (C) and $(\mathrm{D}+\mathrm{I})$ groups, significantly lower $(p<0.05)$ when compared to (D) group. In diabetic insulin and EA treated $(\mathrm{D}+\mathrm{I}+\mathrm{E})$ group, glucose produced was significantly lower $(1.48 \pm 0.16 \mathrm{mg} / \mathrm{g}, p<0.05)$ when compared to (D), (D+I) and (D+E) groups, insignificantly changed $(p>0.05)$, when compared to (C) group.

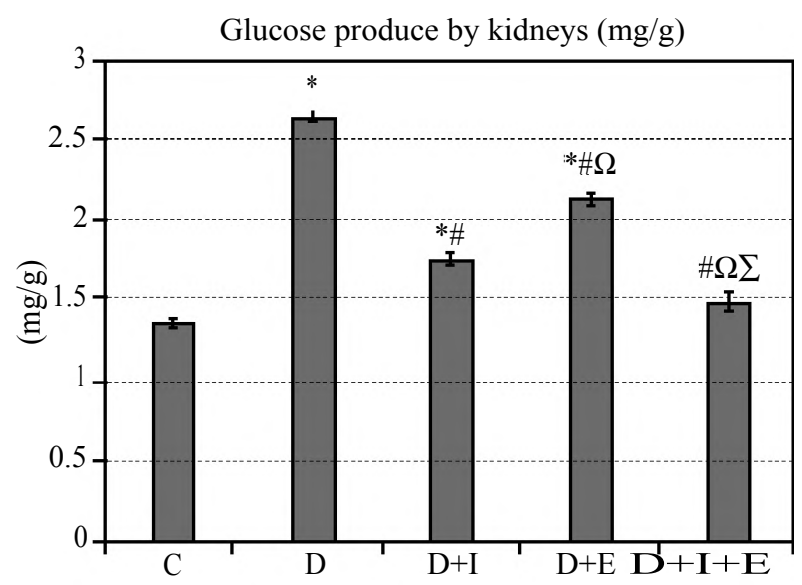

Fig. (2): Level of glucose produce by kidneys ( $\mathrm{mg} / \mathrm{g}$ wet renal tissue) in control non diabetic (C), diabetic (D), diabetic insulin treated $(\mathrm{D}+\mathrm{I})$ diabetic EA treated $(\mathrm{D}+\mathrm{E})$ and diabetic insulin and EA treated (D+I+E) gruops. Results are expressed as mean \pm S.D $(n=12)$. Significance was considered when $p$ value $\leq 0.05$. The marks *,\#, $\Omega$ and $\sum$ indicate that values are significantly different when compared with the corresponding values of $\mathrm{C}, \mathrm{D}, \mathrm{D}+\mathrm{I}$ and $\mathrm{D}+\mathrm{E}$ groups, respectively.

GLUT4. EA therapy at (ST36) for 8 weeks to diabetic rats (in EA treated group) showed a significant increase in the serum insulin and a significant decrease in the glucose levels compared to those obtained results from the diabetic group. The possible explanation was declared by Lee et al., [14], who had reported that, EA increases insulin production and improves insulin sensitivity through induction of endogenous $\beta$-endorphin secretion. $\beta$-endorphins can induce insulin secretion through activation of opioid receptors in pancreatic beta cells and paracrine control of insulin. Also, Cho et al., [15] stated that, EA is involved in activation of nerve fibers in the muscles at the point of insertion sending impulses to the spinal cord and inducing activation of pituitary, hypothalamus and mid brain. This results in increased levels of encephalin, endorphin and serotonin in brain tissue leading to increase insulin secretion. Another possible explanation of the hypoglycemic effect of acupuncture is that, EA mostly lead to cholinergic nerve stimulation that trigger the secretion of acetylcholine. 
The secreted acetylcholine acts on certain receptors on pancreatic beta cells and stimulates insulin signaling pathway and insulin secretion, it also, affects secretion of insulin-like growth factor and insulin receptor substrate 1 (IRS-1) [16]. In addition, Suzukiet al., [17], proved that EA enhances glucose consumption in peripheral tissues leading to reduced serum glucose level. Moreover, Peplow \& McLean [18], reported that EA decreases leptin hormone production by white adipose tissue and may lead to an increase in insulin secretion as leptin is known to reduce insulin secretion by pancreatic beta cells. Bingyan et al., [19], stated another hypoglycemic mechanism for acupuncture, it restores pancreatic morphology and functions by regulation of Glucagon-like peptide-1 (GLP-1) signaling in the pancreas. Thereby decreases fasting blood glucose and up-regulates GLP-1R-GLUT4 pathway in skeletal muscle to restore its glucose uptake. (GLP-1) stimulates synthesis and secretion of insulin and increases sensitivity of target tissues to insulin especially skeletal muscle.

In this study, $\mathrm{HbA}_{1_{\mathrm{c}}} \%$ in the diabetic group was significantly higher than that of the nondiabetic group. These results coincided with $\mathrm{Na}-$ khaee et al., [20], who had found that HbA1c\% increases in STZ-induced diabetic rats and the rate of its increase was directly proportional to the hyperglycemic state. Clinically, $\mathrm{HbA}_{1_{c}} \%$ measurement reflects control of the mean blood glucose level over 2-3 months period in cases of DM. Therefore, follow of diabetic patients by measurement of $\mathrm{HbA}_{1_{\mathrm{c}}} \%$ is considered a definitive sensitive index of long term control of diabetes and its consecutive decline is associated with reducing diabetic complications [21]. Insulin treatment for 8 weeks to the diabetic rats resulted in a significant decrease in $\mathrm{HbA}_{1_{\mathrm{c}}} \%$ when compared to the corresponding values in diabetic group. In support with these findings Bhatia \& Aggarwa [22], found that $\mathrm{HbA}_{1_{\mathrm{c}}} \%$ improves with administration of proper dose insulin in diabetic subject which indicates glycemic control over the last 3 months. Regarding EA treated group in the present study, the $\mathrm{HbA} 1 \mathrm{c} \%$ level was significantly lower when compared to the corresponding values in diabetic group. Consistent with these results Meng et al., [23], had found that EA at (ST36) decreases $\mathrm{HbA}_{1_{\mathrm{c}}} \%$ due to its beneficial effect for lowering blood glucose in diabetic patients.

Actually, it is well established that, $\mathrm{HbA}_{1_{\mathrm{c}}} \%$ is an insensitive measure for assessment of recent pancreatic beta cell function but measurement of $\mathrm{C}$-peptide is an indicator of endogenous insulin secretion, which is co secreted with insulin in a one-to-one molar ratio [24]. In this work, $\mathrm{C}$ peptide level in the diabetic group was significantly lower than that of the non-diabetic group. In line with these findings Lee et al., [25], demonstrated that serum $\mathrm{C}$ peptide level decreases in diabetes due to destruction of beta cell of pancreas. Insulin treatment for 8 weeks to the diabetic rats resulted in a significant increase in serum $\mathrm{C}$ peptide level when compared to the corresponding values in diabetic group. These results were consistent with the study of Crisman et al., [26], who reported that, exogenous insulin administration is associated with increase in $\mathrm{C}$ peptide level, its administration may support glucose stimulated endogenous insulin secretion in insulin-sensitive subjects mostly by its autocrine effects. Regarding EA treated group in the present investigation, the serum $C$ peptide level was significantly higher when compared to the corresponding values in diabetic group. These results show agreement with Subbulakshmi et al., [27], who found that EA at ST36 increased plasma $\mathrm{C}$ peptide due to increase endorphin secretion.These previous tests have argued that, hypoglycemic effect of insulin was significantly higher than hypoglycemic effect of EA, these results were in agreement with Lee et al., [14], who concluded that insulin therapy is the most accepted therapy for treatment of diabetes mellitus and has contributed to improved quality of life for diabetic people. Also, remaining undestroyed beta cells of pancreas by STZ $(45 \mathrm{mg} / \mathrm{kg})$ does not produce more insulin than exogenous insulin administration in insulin treated group, On the other hand, in this study, a significant increase in $\mathrm{C}$ peptide level occurred in EA treated group when compared to insulin treated group. These results show agreement with Cabioglu \& Ergene [28], who found that EA at (ST36) increased plasma $\mathrm{C}$ peptide and insulin level due to increase endorphin secretion from brain tissue and adrenal gland thus the remaining undestroyed beta cells of pancreas after STZ injection produced more endogenous insulin by EA therapy than insulin treatment. It was observed that, treatment of diabetic rats with insulin and EA combined therapy showed a significant decrease in the mean values of blood glucose and $\mathrm{HbA}_{1 \mathrm{c}}$ and a significant increase in the mean values of insulin and $c$ peptide when compared to the corresponding values in diabetic non treated group and insignificant when compared to the corresponding values of nondiabetic group. This finding could be explained by Lin et al., [29], who found that. Although, insulin therapy is the most accepted therapy for treatment of-DM, insulin resistance and insulin insensitivity can be developed by long time of its administration, In order to prevent insulin resistance, other methods 
can be used to enhance insulin sensitivity as acupuncture. It enhances the glucose lowering effect of exogenous insulin and regulates the secretion of insulin.

Moreover, in this study, STZ administration resulted in significant decrease in the mean values of liver glycogen and significant increase in the mean values of glucose produced by kidneys when compared to the corresponding values in nondiabetic group. Basically, the decreased serum insulin level leads to a decrease of glucose utilization by insulin-sensitive tissues such as skeletal muscle and adipose tissue and increases both hepatic and renal glucose production by glycogenolysis and gluconeogenesis. Also, insulin deficiency limits ability of diabetic liver to store glucose in the form of glycogen resulting in persistent hyperglycemia [30]. In insulin treated group, the liver glycogen was significantly higher and the glucose produced by kidneys was significantly lower when compared to the corresponding values in diabetic group. This can be explained by immediate action of insulin which stimulates glycogen synthesis by activation of glycogen synthase and promotes its dephosphorylation by inhibition of kinases such as protein kinaseA ( PKA) or glycogen synthase kinase 3 (GSK-3) and activation of protein phosphatase 1 (PP1) [31]. Also, Barthel \& Schmoll [32] proved that exogenous insulin regulates glucose metabolism by suppressing the expression of gluconeogenic enzyme genes for the key gluconeogenic enzymes phosphoeno lpyruvate carboxykinase (PEPCK) and glucose-6-phosphatase (G-6Pase) Regarding EA treated group, liver glycogen was significantly higher and the glucose produced by kidneys was significantly lower when compared to the corresponding values in diabetic group. These results were consistent with the study of Ma. [33], who suggested that EA stimulation at the (ST36) induces secretion of endogenous betaendorphin that reduces plasma glucose concentration due to its ability to induce insulin secretion. By treatment of diabetic rats with combined insulin and EA therapy, there was a significant increase in the mean values of liver glycogen and significant decrease in the mean values of glucose produced by kidneys when compared to the corresponding values in diabetic group and insignificant when compared to the corresponding values in nondiabetic group. In support with these findings, Chang et al., [8] had found that EA at (ST36) improves glucose tolerance. Thus, EA could be considered as an adjuvant method for improving insulin sensitivity and enhancing its hypoglycemic activity in rats.
Conclusion: EA can be used as an adjuvant therapy in diabetic rats.

\section{Acknowledgments:}

I would like to express sincere gratitude and deep appreciation to Prof. Dr. Mohamed Soliman Rizk, Assistant Professor of Biochemistry Faculty of Medicine, Menoufia University for his great help to complete this laboratory results.

\section{References}

1- ROTHER K.I.: Diabetes Treatment. N. Engl. J. Med., 356: 1499-1501, 2007.

2- ISHIZAKI N., OKUSHI N., YANO T. and YAMAMURA Y.: Improvement in glucose tolerance as a result of enhanced insulin sensitivity during electro acupuncture in spontaneously diabetic Goto-Kakizaki rats. Metabolism, 58 (10): 1372-1378, 2009.

3- XU P., QIAN X., SCHATEZ D., CUTHBERTSON D., KRISCHER J. and The DPT-1 Study Goup: Distribution of $\mathrm{C}$ peptide and its determinantsin North American children at risk for type 1 diabetes. Diabetic care, 37: 1959-1965, 2014

4- KJEMS L.L., CHRISTIANSEN E., VØLUND A., BERGMAN R.N. and MADSBAD S.: Validation of methods for measurement of insulin secretion in humans in vivo. Diabetes, 49: 580-588, 2000.

5- TONG Y., GUO H. and HAN B.: Fifteen-day Acupuncture treatment relieves diabetic peripheral neuropathy. J. Acupunct. Meridian. Stud., 3(2): 95-103, 2010.

6- PATIL S.B., GHADYALE V.A., TAKLIKAR S.S., KULKARNI C.R. and ARVINDEKAR A.U.: Insulin secretagogue, alpha-glucosidase and antioxidant activity of some selected spices in streptozotocin-induced diabetic rats. Plant Foods Human Nutrition, 66: 85-90, 2011.

7- UNLUCERCI Y., BEKPINER S. and GURDOL F.: A study on the relationship between homocysteine and diabetic nephropathy in rats. Pharmacol. Res., 45 (3): 249-252, 2002.

8- CHANG S.L., LIN K.J., LIN R.T., HUNG P.H., LIN J.G. and CHENG J.T.: Enhanced insulin sensitivity using electroacupuncture on bilateral Zusanli acupoints (ST36) in rats. Life Sci, 79 (10): 967-71, 2006.

9- HUO Z.G., LI Q., TIAN G.H., ZHOU C.M., WEI X.H. and PAN C.S.: The ameliorating effects of long term electroacupuncture on cardiovascular remodelling in spontaneously hypertensive rats. Complementary and Alternative Medicine, 14: 118, 2014.

10- IWA M., TATEIWA M., SAKITA M., FUJIMIYA M. and TAKAHASHI T.: Anatomical evidence of regional specific effects of acupuncture on gastric motor function in rats. Autonomic Neuroscience, 137 (1-2): 67-76, 2007.

11- TANG N.M., DONG H.W., WANG X.M., TSUI Z.C. and HAN J.S.: Cholecystokinin antisense RNA increases the analgesic effect induced by electroacupuncture or low dose morphine: Conversion of low responder rats into high responders. Pain, 71: 71-80, 1997.

12- BISWAS A., BEGUM S.A., GHOSH B., NASER S.M., MANA B., NAND Y. and MONDAL S.: Effect of nic- 
orandil on blood glucose level in normal rats. IJPSR., 4 (8): 3000-3003, 2013.

13- STANG J. and STORY M. (EDS).: Guidelines for Adolescent Nutrition Services. Chapter 14. Diabetes Mellitis: Type, 1 and Type, 2 (14): 167-182, 2005.

14- LEE Y.C., LI T.M., TZENG C.Y., CHENG Y.W., CHEN Y.I. and HO W.J.: Electroacupuncture induced cholinergic nerves activation enhances the hypoglycemic effect of exogenous insulin in a rat model of streptozotocin = induced diabetes. Experimental Diabetes Research, 138: $1-7,2011$

15- CHO T.H. and PARK K.M.: Use of Acupuncture Point Injection with Placental Extract for Treatment of Complex Regional Pain Syndrome. J. Pain. Relief, 5: 246-249, 2016.

16- SIMADIBRATA C., BUDIHARDJO F.A. and SRILESTARI A.: The effect of electroacupuncture at the MA-IC 3 endocrine ear acupoint on fasting blood glucose levels in type 2 diabetes mellitus patients. Journal of Physics, 884: 012-129, 2017.

17- SUZUKI H., NAKAMURA H., ISHIGAMI T., KAWASE Y., YAMADA A. and MINAGAWA M.: Effects of acupuncture stimulation on blood glucose concentration in the Otsuka Long-Evans Tokushima Fatty (OLETF) rat, an animal model for type-2 diabetes mellitus. Med. Sci. Monit. Basic. Res., 20: 70-75, 2014.

18- PEPLOW P.V. and MCLEAN G.T. Z.: Repeated Electroacupuncture: An Effective Treatment for Hyperglycemia in a Rat Model. J. Acupunct Meridian Stud, 8 (2): 71-76, 2015.

19- BINGYAN C., RUI L., HUANHUAN T., YANJIA M., XIAOGANG H. and NING J.: Effect on glycemia in rats with type 2 diabetes induced by streptozotocin: Lowfrequency electro-pulse needling stimulated Weiwanxiashu (EX-B 3) and Zusanli (ST 36). J. Tradit. Chin. Med., 36 (6): 768-778, 2016.

20- NAKHAEE A., BOKAEIAN M., SARAVANI M., FARHANGI A. and AKBARZADEH A.: Attenuation of oxidative stress in streptozotocin-induced diabetic rats by eucalyptus globules. Indian Journal of Clinical Biochemistr, 24 (4): 419-425, 2009.

21- SELVIN E., STEFFES M.W., ZHU H., MATSUSHITA K.,WAGENKNECHT L. and PANKOW J.: Glycated hemoglobin, diabetes, and cardiovascular risk in nondiabetic adults. N. Engl. J. Med., 362 (9): 800-811, 2010.

22- BHATIA E. and AGGARWA A.: Insulin Therapy for Patients with Type 1 Diabetes. Supplement of Japi-July Vol., 55: 29-40, 2007.
23- MENG H., HAO J.D., WANG H.C., ZHAO J.Y., ZHAO C.L. and ZHAI X.: Effects of different frequencies of electroacupuncture on blood glucose level in impaired glucose tolerance patients. Zhen. Ci. Yan. Jiu., 36: 220 223, 2011.

24- MCGEE P., STEFFES M., NOWICKI M., BAYLESS R., KLUG P. and DCCT/EDIC Research Group: Insulin secretion measured by stimulated c peptide in long established type 1 diabetes in the diabetic control and complications trial (DCCT)/Epidemiology of diabetes interventions and complications (EDIC) cohort: A pilot study. Diabet. Med., 31: 1264-1268, 2014.

25- LEE T.H., KWON A.R., KIM Y.J., CHAE H.W., KIM H.S. and KIM D.H.: The Clinical Measures Associated with C-peptide Decline in Patients with Type 1 Diabetes over 15 Years. Korean. Med. Sci., 28: 1340-1344, 2013.

26- CRISMAN M., LUCCHETTAL L., LUETHI N., CIOCCARI L., LAM Q. and EASTWOOD G.M.: The effect of insulin administration on c-peptide in critically ill patients with type 2 diabetes. Ann. Intensive Care, 7: 50, 2017.

27- SUBBULAKSHMI R., SIVAKUMAR G. and MURTHY S.N.: Zhongwan (CV 12) acupoint therapy effect in B ebdorphin and $\mathrm{c}$ peptide in induced diabetic male rate. International Journal of Advanced in Interdisciplinary Research, 4 (3): 7-11, 2017.

28- CABIOGLU M.T and ERGENE N.: Changes in levels of serum insulin, C-peptide and glucose after electroacopuncture and diet therapy in obese women. American Journal of Chinese Medicine, 34 (3): 367-376, 2006.

29- LIN R.T., PAI H.C., LEE Y.C., TZENG C.Y., CHANG C.H. and HUNG P.H.: Electroacupuncture and Rosiglitazone Combined Therapy as a Means of Treating Insulin Resistance and Type 2 Diabetes Mellitus: A Randomized Controlled. Evidence-Based Complementary and Alternative Medicine, Article ID 969824, 9 pages, 2013.

30- COLBERG S.R., LAAN B.A., DASSAU E. and KERR D.: Physical activity and type 1 diabetes: Time for a rewire? Diabetes Science and Technology, 9 (3) 609-618, 2015.

31- SALTIEL A.R and KAHN C.R.: Insulin signalling and the regulation of glucose and lipid metabolism. Nature, 414: 799-806, 2001.

32- BARTHEL A. and SCHMOLL D.: Novel concepts in insulin regulation of hepatic gluconeogenesis. Am. J. Physiol. Endocrinol. Metab., 285: 685-692, 2003.

33- MA S.X.: Neurobiology of acupuncture: Toward CAM. Evidence-Based Complementary and Alternative Medicine, Vol., 1: 41-47, 2004. 


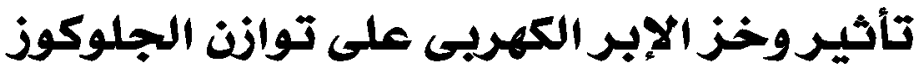

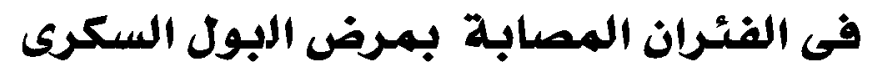

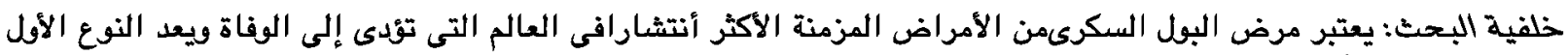

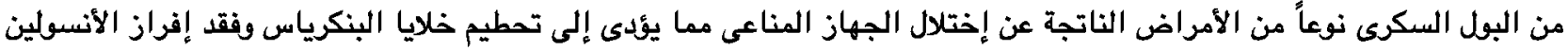

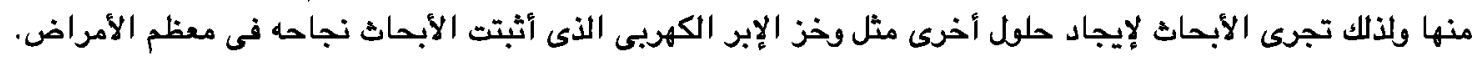
هدف البحث: تقييم تأثير وخز الإبر الكهربى على توازن الجلوكوذ فى الفئران المصابة بمرض البول السكرى .

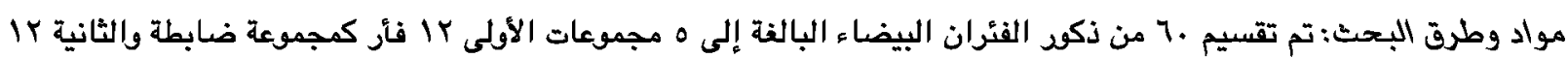

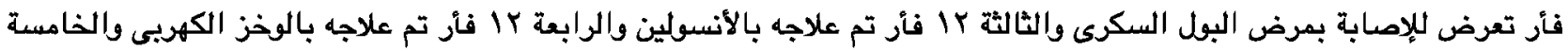

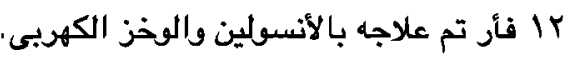

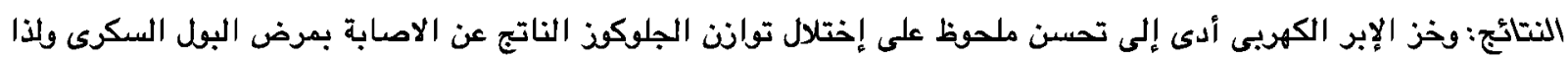

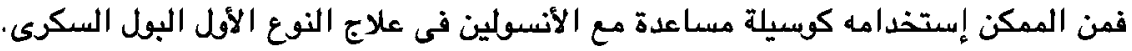

